\title{
Prince de Joinville, Vieux Souvenirs 1818-1848
}

\section{Lise Sabourin}

\section{(2) OpenEdition}

\section{Journals}

\section{Édition électronique}

URL : http://journals.openedition.org/studifrancesi/6362

DOI : 10.4000/studifrancesi.6362

ISSN : 2427-5856

\section{Éditeur}

Rosenberg \& Sellier

\section{Édition imprimée}

Date de publication : 1 novembre 2010

Pagination : 572

ISSN : 0039-2944

\section{Référence électronique}

Lise Sabourin, « Prince de Joinville, Vieux Souvenirs 1818-1848 », Studi Francesi [En ligne], 162 (LIV | III) | 2010, mis en ligne le 30 novembre 2015, consulté le 11 janvier 2021. URL : http://

journals.openedition.org/studifrancesi/6362 ; DOI : https://doi.org/10.4000/studifrancesi.6362

\section{Ce document a été généré automatiquement le 11 janvier 2021.}

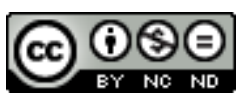

Studi Francesi è distribuita con Licenza Creative Commons Attribuzione - Non commerciale - Non opere derivate 4.0 Internazionale. 


\title{
Prince de Joinville, Vieux Souvenirs 1818-1848
}

\author{
Lise Sabourin
}

\section{RÉFÉRENCE}

PRINCE DE JOINVILLE, Vieux Souvenirs 1818-1848, édition présentée et annotée par Daniel MEYER, Paris, Mercure de France, «Le Temps retrouvé», 2008, pp. 419.

1 Nous devons cette réédition d'un livre paru au Mercure de France en 1970, puis en 1986, à Daniel Meyer qui en assure l'introduction (pp. 11-16), l'annotation, l'index nominum et la bibliographie finale. Le prince de Joinville, frère du duc d'Aumale, dont il partage l'exil après 1848, a rédigé ces Vieux Souvenirs sur la première partie de sa vie, de la Restauration à la chute de la Monarchie de Juillet paternelle qu'il a toujours considérée comme un "gouvernement d'occasion» d'origine "hybride et illégitime», lui qui est resté toute sa vie partisan de la branche aînée au point de favoriser la réconciliation des Orléans avec Henri V.

2 Cet officier (vice-amiral, il commandait la flotte française en Algérie en 1848, après avoir été chargé, contre son avis, du retour des Cendres), fidèle à la France jusqu'au bout (après avoir suivi les opérations de la guerre de Sécession avec ses neveux, le comte de Paris et le duc de Chartres, il offre vainement ses services à l'armée de Loire en 1870 , siège dans les conseils de la Marine après l'armistice et se fait élire député sous la $3^{\mathrm{e}}$ République), est aussi un prince du sang, attaché à la vie de cour comme à la vie parisienne. S'il demeure discret par pudeur sur la famille royale, très unie, mais assez terne, ses Souvenirs offrent en revanche un panorama vivant des coulisses du théâtre, des arts et de la haute société d'avant 1848 tout autant que du déroulement d'une vie militaire. 